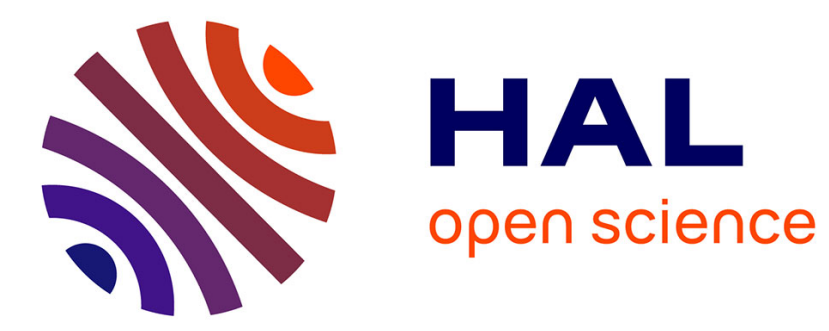

\title{
Optimizing storage of a catch crop before biogas production: Impact of ensiling and wilting under unsuitable weather conditions
}

Ruben Teixeira Franco, Pierre Buffière, Rémy Bayard

\section{To cite this version:}

Ruben Teixeira Franco, Pierre Buffière, Rémy Bayard. Optimizing storage of a catch crop before biogas production: Impact of ensiling and wilting under unsuitable weather conditions. Biomass and Bioenergy, 2017, 100, pp.84-91. 10.1016/j.biombioe.2017.03.017 . hal-01692787

\section{HAL Id: hal-01692787 https://hal.science/hal-01692787}

Submitted on 25 Jan 2018

HAL is a multi-disciplinary open access archive for the deposit and dissemination of scientific research documents, whether they are published or not. The documents may come from teaching and research institutions in France or abroad, or from public or private research centers.
L'archive ouverte pluridisciplinaire HAL, est destinée au dépôt et à la diffusion de documents scientifiques de niveau recherche, publiés ou non, émanant des établissements d'enseignement et de recherche français ou étrangers, des laboratoires publics ou privés. 


\title{
Optimizing storage of a catch crop before biogas production: impact of ensiling
} and wilting under unsuitable weather conditions

\author{
Rúben Teixeira Franco, Pierre Buffière, Rémy Bayard ${ }^{1}$ \\ Université de Lyon, INSA Lyon, DEEP Laboratory, EA7429, F-69621 Villeurbanne \\ cedex, France
}

\begin{abstract}
Ensiling and open-air storage of up to 98 days were assessed for a catch crop in order to identify the best management practices before its use as feedstock for anaerobic digestion. For ensiling, this included the study of the effect of wilting limited by unsuitable weather conditions. Results showed that after 98 days, methane potential of biomass open-air stored corresponded to $18 \%$ of the one for the ensiling of the same feedstock. Wilting was inefficient while witnessing unfavorable weather conditions at harvesting. Even if prolonged wilting periods under severe conditions led to decrease of moisture content, it did not provide improvements on long-term conservation of methane potential. For high moisture silage, instability of fermentation was offset by gains in biochemical accessibility. In such conditions, biomass should be promptly ensiled without wilting. Leachate produced during ensiling of high moisture crops should be collected and used for biogas production.
\end{abstract}

Keywords: Wilting; Storage; Ensiling; Anaerobic digestion; Methane potential

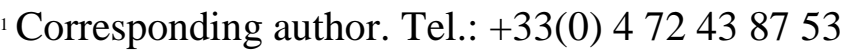

E-mail addresses: ruben.teixeirafranco@insa-lyon.fr (R. Teixeira Franco), pierre.buffiere@insa-lyon.fr (P. Buffière), remy.bayard@insa-lyon.fr (R. Bayard) 


\section{Highlights}

- Ensiling is a far more appropriated conservation method than open-air storage

- Wilting is ineffective if weather conditions are unfavorable

- Biomass should be promptly ensiled without wilting

- Instability of high moisture silage is offset by gains in biochemical accessibility

- Leachate produced during ensiling should be collected for biogas production

\section{Abbreviations}

AA, acetic acid; AD, anaerobic digestion; ADF, acid detergent fiber; ADL, acid detergent lignin; BA, butyric acid; BMP, biochemical methane potential; CEL, cellulose; HEM, hemicellulose; LA, lactic acid; LAB, lactic acid bacteria; LIG, lignin; $\mathrm{NDF}$, neutral detergent fiber; $\mathrm{NH}_{3}-\mathrm{N}$, ammonia nitrogen; $\mathrm{TKN}$, total Kjeldahl nitrogen; TS, total solids; VS, volatile solids; WSC, water soluble carbohydrates; VFA; volatile fatty acids

\section{Introduction}

Seasonality of crops and other agricultural wastes used for biogas production is at the origin of storage requirements before anaerobic digestion (AD). Since biogas production through $\mathrm{AD}$ should operate continuously throughout the year, seasonal biomass feedstock need to be preserved for prolonged periods, which may reach up to 6 months in some cases.

Among the current preservation methods, ensiling emerges as a logical choice to store wet biomass for energy production purposes. Based on biochemical processes, ensiling provides an anaerobic environment suitable for bacterial fermentation, which leads to biomass acidification, limiting further degradation and energy losses. 
Together with the nature of the feedstock, air presence, storage duration or the use of additives, the control of the moisture content is one of the key parameters for the success of feedstock ensiling before AD [1]. Indeed, it is commonly shared that low moisture contents slow down bacterial growth, leading to a more restricted fermentation and better silage preservation [2-5]. Furthermore, silages with at least $25 \%$ of total solids content (TS) may prevent leachate formation during ensiling [6-8], avoiding potential energy losses due to seepage.

Field wilting (i.e. natural air-drying of crops after harvesting) prior to ensiling is the most common method to achieve higher TS contents for biomass crops when moisture content is excessively high. Besides being inexpensive, it may enable water evaporation with little effect on the remaining chemical characteristics if short wilting duration (around $6 \mathrm{~h}$ ) is used $[3,9,10]$. However, wilting effectiveness is strongly dependent on weather conditions of the harvest site. In fact, natural environmental conditions such as solar radiation, vapor pressure, rainfall and eventually wind speed are correlated with the drying rate of biomass [2]. Consequently, when unfavorable weather conditions are present at harvesting, prolonged wilting durations must be used to obtain the desired TS content. In such cases, it is suggested that other chemical changes beyond water evaporation occur, which might influence ensiling conservation as well. For instance, Carpintero et al. [10] observed an impact of $48 \mathrm{~h}$ wilting on the water-soluble carbohydrates (WSC) and ammonia nitrogen $\left(\mathrm{NH}_{3}-\mathrm{N}\right)$ content of ryegrass-clover. Likewise, Dawson et al. [11] studied field wilting durations of 28 and $52 \mathrm{~h}$ for perennial ryegrass and reported an impact of wilting on silage chemical characteristics, particularly on the $\mathrm{pH}$ and the buffering capacity. However, results on the impact of prolonged wilting durations on the conservation of the biochemical methane potential 
(BMP) during ensiling are still scarce and inconclusive. To our best knowledge, only Pakarinen et al. [12] have tested this parameter and observed better BMP conservation during ryegrass ensiling after $48 \mathrm{~h}$ drying, while an opposite effect was obtained for grass silage.

The objective of this study was thus to compare ensiling and open-air storage as methods for preservation of a catch crop before biogas production. For ensiling, the aim was to optimize the management practices of the feedstock when unfavorable weather conditions are present at harvesting. Both fermentative profiles and BMP were monitored at different stages of preservation, which enabled a detailed analysis of the phenomena involved during storage.

\section{Material and methods}

\subsection{Feedstock}

Raw material used was a sample of a catch crop harvested on 9 November 2015 from an agricultural site in the Rhône-Alpes region of France (Gaec Béreyziat, Les Teppes, 01340 Béréziat, France). Biomass was composed by a mixture of sunflower, sorghum, peas, Vicia sp. and Trifolium alexandrinum.

\subsection{Wilting process}

Storage preparation procedure is summarized in Figure 1. After harvesting, part of the fresh biomass (10.1\% TS) was ensiled and the remaining fraction was wilted. Nonsuitable weather conditions were recorded during wilting: daily average temperatures ranged between $7.7-14.9^{\circ} \mathrm{C}$; extremely cloudy sky along with fog patches. After $72 \mathrm{~h}$ of wilting, the dried sample had $14.1 \%$ of TS content. At this point, part of the $72 \mathrm{~h}$-wilted biomass was ensiled and the remaining amount was moved to an air-ventilated stove at $35^{\circ} \mathrm{C}$, in order to be able to test a larger range of moisture content in the ensiling assays. 
After a total of $96 \mathrm{~h}$ of wilting, the last fraction of biomass $(38.7 \% \mathrm{TS})$ was removed from the stove, equilibrated to room temperature and then ensiled. Fresh and wilted biomass were chopped to theoretical particle size of $8 \mathrm{~mm}$ with a rotary shear shredder immediately before storage. This particle size was chosen taking into account the recommendations of Herrmann et al. $[13,14]$ for a compromise between high methane conservation rates and low chopping costs. Biomass was manually mixed between each step of storage preparation and samples used for storage assays were taken in representative quantity of raw material, i.e. $10 \%$.

\subsection{Storage approach}

Storage assays were conducted at laboratory scale to monitor the impact of ensiling and prolonged wilting on biomass conservation. To evaluate ensiling impact, an aerobic control storage test was also performed for the $96 \mathrm{~h}$-wilted sample. All storage tests were performed in $3.5 \mathrm{~L}$ airtight round plastic storage drums modified to allow the gas to escape. In order to enable the output of gas produced and at the same time minimizing headspace, silos were filled up to $2.55 \mathrm{~L}$ with raw material at packing density of $0.7 \mathrm{~kg} / \mathrm{L}$, the remaining volume being filled with gravel, using a geotextile membrane to separate it from biomass. Silo sealing was different depending on the storage method tested. For ensiling assays, proper plastic lid and rubber ring were used and its airtightness was reinforced with silicone sealant. For aerobic storage purposes no cover was used and the silo was left air-open. Once sealed, the silos were weighed and placed in a temperate room at $25 \pm 2^{\circ} \mathrm{C}$ for a defined period. Storage duration varied between 7 , 14, 28 and 98 days. A total of 16 (4 operating conditions x 4 storage durations) laboratory silos were used. 


\subsection{Chemical analysis}

Chemical analysis procedure after sampling is illustrated in Figure 2. For each tested duration, one silo (per tested condition) was opened and weighed, biomass was homogenized and two samples were taken. One was used for direct analyses on the crude material and the other one was mixed with water in order to get two fractions: a water-soluble phase and a particulate phase. This leaching test was performed with a 10:1 water/dry mater ratio during $2 \mathrm{~h}$ under constant bottle rotation. Phase separation was achieved by centrifugation followed by $0.7 \mu \mathrm{m}$ particle size filtration. Finally, the particulate phase was dried at $70^{\circ} \mathrm{C}$ until constant weight and ground at $2 \mathrm{~mm}$ theoretical length. Crude material/water-soluble and particulate samples were stored at $4{ }^{\circ} \mathrm{C}$ and $20^{\circ} \mathrm{C}$, respectively, until use.

Crude material was analyzed for its TS content, volatile solids (VS) content and BMP. For the water-soluble phase, besides TS/VS content, $\mathrm{pH}$, WSC, volatile fatty acids (VFA), $\mathrm{NH}_{3}-\mathrm{N}$ and total Kjeldahl nitrogen (TKN) contents were determined. Particulate solid was analyzed for its TS/VS, TKN and cell wall constituents content.

TS was measured by oven drying at $105^{\circ} \mathrm{C}$ during $24 \mathrm{~h}$ and VS was subsequently burned for $2 \mathrm{~h}$ at $550^{\circ} \mathrm{C}$. Since TS/VS contents are underestimated due to the loss of volatile compounds during the drying tests [15], the measures were corrected using the equation suggested by Porter and Murray [16]. pH was measured by a Consort C3020 device with a SP10B pH-electrode. VFA and WSC contents were determined with high performance liquid chromatography (LC Module 1 plus, Waters) equipped with a Supelcogel ${ }^{\mathrm{TM}} \mathrm{C}-610 \mathrm{H}$ column $(300 \times 7.8 \mathrm{~mm}$, Sigma-Aldrich), both refractive index (RID) and UV detectors and operating with $\mathrm{H}_{3} \mathrm{PO}_{4} 0.1 \% \mathrm{v}$ as solvent (flow rate of $0.5 \mathrm{~mL} / \mathrm{min}$ ). WSC content was estimated as the sum of glucose, xylose, galactose, 
mannose, arabinose and cellobiose and was determined using the UV detector (210nm). Total VFA was calculated as the sum of lactic, formic, acetic, propionic, butyric, valeric and caproic acids content obtained with the RID detector. Neutral detergent fiber (NDF), acid detergent fiber (ADF) and acid detergent lignin (ADL) were analyzed through Van Soest and Wine [17] modified extractions method, based on XP U44-162 French standard. Cellulose content (CEL) was calculated as NDF minus ADF, hemicellulose (HEM) as ADF minus ADL and lignin (LIG) as approximatively equal to ADL.TKN and $\mathrm{NH}_{3}-\mathrm{N}$ were determined through the procedure described in the NF EN 25663 French standard.

The interest of our experimental procedure is, first, to be able to compare the results of composition and BMP to the initial mass of product used since the weight loss is monitored. The results for the chemical analysis will thus be presented in two ways: based on $\% \mathrm{VS}_{\text {added }}$ or $\% \mathrm{VS}_{\text {original. }} \mathrm{VS}_{\text {added }}$ relates to the organic matter of the sample analyzed. The results based on $\mathrm{VS}_{\text {original }}$ take into account the loss of volatile solids during storage and allows the study of the results based on the VS of the initial material.

\subsection{Biochemical methane potential tests}

Batch anaerobic digestion tests were performed for crude material samples. Tests were conducted in a temperate room at $35^{\circ} \mathrm{C}$ using glass vessels of $2 \mathrm{~L}$. Vessels were filled with at least $5 \mathrm{~g}_{\mathrm{VS}}$ of sample, inoculum in way to keep a substrate/inoculum VS ratio of 0.5 and a certain volume of a mineral solution to achieve $60 \%$ of the total volume of the vessel. The inoculum used (TS: $2.6-3.0 \% \mathrm{wt}$; VS: $1.8-2.0 \% \mathrm{wt}$ ) was a digested sludge originating from the wastewater treatment plant of La Feyssine, Lyon, France. The mineral solution, which contains essential elements to microbial growth and also gives the solution a buffer able to control any $\mathrm{pH}$ adjustments, was prepared according to the 
recommendations of ISO 11734:1995 standard. Once filled, reactors were purged with a $\mathrm{N}_{2} / \mathrm{CO}_{2}$ mixture $(80 / 20 \% \mathrm{v})$ for about 5 minutes and then sealed and equilibrated at $35^{\circ} \mathrm{C}$. In order to subtract the volume of methane produced by the inoculum from the one originated from the sample, controls with only inoculum and mineral solution were performed for each batch series. All tests were performed in triplicates.

Biogas production was followed by the pressure measurement using a Digitron precision manometer. Biogas was released when the pressure exceeded $1200 \mathrm{hPa}$. Biogas composition was determined using an Agilent 3000 micro gas chromatography with thermal conductivity detector (GC-TCD). Molsieve 5A (14 m length; pore size: 5 Å) and PoraPlot A (10 m length; 0.320 mm ID) columns were used as stationary phases for GC-TCD, with Argon and Helium as carrier gases, respectively. Biogas production and composition were analyzed at least 8 times during batch tests and BMP was considered achieved when daily vessel overpressure of controls equalized the sample ones. The BMP tests followed the recommendations provided by Holliger et al. [18].

\section{Results and discussion}

\subsection{Raw materials characterization}

Results of chemical analysis on fresh and wilted biomass before storage are summarized in Table 1. Fresh catch crop was characterized by a low level of TS (10.1\%) and high WSC content in the organic matter $(12.0 \% \mathrm{VS})$. These values are important to understand ensiling fermentation, since silage quality will strongly rely on TS and WSC content of feedstock [1]. High WSC level of fresh material should enable a prompt acidification of silage by lactic acid bacteria (LAB) fermentation. However, secondary fermentation will be favored at low TS content if extremely acid environments are not reached. This should preclude biomass stabilization and lead to substantial VS losses. 
To avoid the risk of having unstable silages due to low TS content, wilting was performed before storage. As mentioned earlier, natural drying of biomass had a minor effect on the moisture content of feedstock. TS content only increased from $10.1 \%$ to $14.1 \%$ of total biomass after $72 \mathrm{~h}$-wilting. Drying ineffectiveness should be closely linked to the poor weather conditions recorded during wilting process.

At the same time, TS content of 96h-wilted biomass increased to $38.7 \%$, due to the use of an air-ventilated stove at $35^{\circ} \mathrm{C}$ on the last $24 \mathrm{~h}$ of drying. Besides, $96 \mathrm{~h}$-wilting had a substantial impact on WSC, leading to degradation of more than half of the initial content. This suggest that some drying conditions, including high temperatures and wind speed (which may occur in summer), may lead to important organic matter losses before storage.

Wilting duration also had an impact on $\mathrm{pH}$ values: it decreased from 6.4 to 6.2 after 72h-wilting and to 5.8 after $96 \mathrm{~h}$-wilting. Nevertheless, the reason for this remained unclear, as VFA contents were stable and almost negligible during wilting. Regarding fibers constituents, prolonged periods of wilting had a negative impact on cellulose preservation. Finally, some fluctuations were recorded on $\mathrm{NH}_{3}-\mathrm{N}$ and $\mathrm{TKN}$ fractions, but no correlation was found between their content and wilting duration.

\section{2. $\quad$ Storage impact on chemical characteristics}

A major advantage is evidenced in using ensiling as biomass conservation method rather than open-air storage, Table 2. Regarding aerobic treatment, significant organic matter degradation occurred from the first week of storage: $21.9 \%$ and $68.8 \%$ of original VS content was lost after 7 and 98 days, respectively. This was a result of degradation of both non-structural and structural carbohydrates and organic nitrogen 
compounds present in the raw material. In fact, more than $99 \%$ of the original WSC content had been consumed after only 7 days of open-air storage. This led to organic matter losses, as no accumulation of VFA was recorded. For the structural carbohydrates, the degradation took place all along storage in aerobic environment as can be observed in Figure 3, resulting after 98 days in $78 \%$ and $47 \%$ losses of original hemicellulose and cellulose contents, respectively. Degradation of organic nitrogen was evidenced by $\mathrm{TKN}$ decrease from 5.1 to $3.8 \% \mathrm{VS}_{\text {original }}$ and ammonia nitrogen increase from 4.5 to $46.8 \%$ TKN until 28 days of aerobic storage. Moreover, between 28 and 98 days of storage, the $\mathrm{NH}_{3}-\mathrm{N}$ and $\mathrm{TKN}$ contents dropped dramatically, resulting in around $85 \%$ ammonia loss during this period. This showed that, besides organic matter degradation, undesired ammonia emissions into the atmosphere are favored by open-air storage. This should be a result of the impact of a continuous $\mathrm{pH}$ increase for aerobic environment, from 5.8 at start to 9.6 after 98 days of storage, on the $\mathrm{NH}_{3}-\mathrm{NH}_{4}{ }^{+}$ equilibrium reaction and $\mathrm{NH}_{3}$ stripping. Additionally, fungi development was detected throughout aerobic storage. This suggests that microbial degradation of organic matter took place via an aerobic metabolism producing $\mathrm{CO}_{2}$ and microbial biomass.

In contrast, during ensiling, biomass is mainly subject to microorganism capable of anaerobic proliferation. For the same raw material used in open-air storage (96h-wilted biomass), ensiling enabled acidification, resulting in $\mathrm{pH}$ values between 4.9 after 7 days and 4.4 at the end of storage. A continuous production of lactic acid from available carbohydrates sources during ensiling was behind it. Lactic acid content varied from $7.7 \% \mathrm{VS}_{\text {added }}$ after 7 days and $11.6 \% \mathrm{VS}_{\text {added }}$ after 98 days of storage. Butyric acid production was negligible during ensiling of $96-\mathrm{h}$ wilted biomass. Consequently, silage was stabilized by escaping from the $\mathrm{pH}$ range where spoiling anaerobic microorganisms 
are active. This limited VS losses to only $5 \%$ of the ones obtained in aerobic environment after 98 days.

Nevertheless, results showed that biomass stabilization through ensiling strongly depended on the TS content. For both fresh and 72h-wilted biomass (low TS contents) faster acidification occurred and after 7 days of ensiling $\mathrm{pH}$ was already at 4.0 and 4.2, respectively. This was a result of a more extensive LAB activity for lower TS contents, as lactic acid content was $18.9 \% \mathrm{VS}_{\text {added }}$ after 7 days for these crops. However, from 14 days of ensiling, low TS crops revealed to be instable and fermentation profiles reverse direction. In fact, lactic acid content of fresh ensiled biomass dropped from $23.1 \% \mathrm{VS}_{\text {added }}$ at 14 days to $0.5 \% \mathrm{VS}_{\text {added }}$ and $0 \% \mathrm{VS}_{\text {added }}$ after 28 and 98 days, respectively. Similarly in $72 \mathrm{~h}$-wilted silage, lactic acid content decreased from $17.9 \% \mathrm{VS}_{\text {added }}$ at 14 days to $8.1 \% \mathrm{VS}_{\text {added }}$ after 28 days and to nothing at the end of storage. In the same period of time, butyric acid started to be produced in both low TS silages. Final butyrate contents of $8.3 \% \mathrm{VS}_{\text {added }}$ for fresh biomass and $5.5 \%$ for $72 \mathrm{~h}$ wilted silage were obtained. The degradation of lactic acid and the concomitant production of butyric acid at low TS content indicates that secondary fermentation occurred through undesired clostridial activity. Saccharolytic clostridial fermentation is mainly based on sugars and lactic acid consumption as energy source via similar pathways, producing not only butyric acid but also carbon dioxide and hydrogen [2]. Besides the unstable behavior, this will also lead to VS and energy losses. Moreover, clostridial activity is associated with losses of acidity. This is explained by the fact that butyric acid is a much weaker acid than lactic acid and since only one mole of butyrate is produced from two moles of lactate [2]. Indeed, the $\mathrm{pH}$ of fresh ensiled biomass increased from 4.2 at 14 days to 5.6 at the end of storage. Likewise, $72 \mathrm{~h}$-wilted silage 
presented a huge increase of $\mathrm{pH}$ from 4.4 at 14 days to 7.0 at 98 days of storage. Major impact of clostridial fermentation on VS losses was also observed at low TS. After 98 days of ensiling, cumulative organic matter losses of fresh and 72h-wilted biomass reached $25.8 \%$ and $16.8 \%$, respectively.

The instability of higher moisture crops was also illustrated by an increasing ammonia nitrogen content during ensiling. $\mathrm{NH}_{3}-\mathrm{N}$ fraction varied from $12.3 \% \mathrm{TKN}$ at 14 days to $40.2 \% \mathrm{TKN}$ at the end of fresh biomass ensiling. Similarly, $\mathrm{NH}_{3}-\mathrm{N}$ content of $72 \mathrm{~h}-$ wilted silage increased from $15.3 \% \mathrm{TKN}$ to $37.0 \% \mathrm{TKN}$ in the same period of storage. Proteolytic clostridial activity, which is favored by disturbances on silage acidification, should be in the origin of this increase. This type of clostridia can selectively ferment amino acids and amines mainly into ammonia and carbon dioxide. Besides nutrients spoilage, proteolytic clostridia may have an impact on energy losses if an alkaline $\mathrm{pH}$ is reached. Since unstable silage never exceeded a $\mathrm{pH}$ value of 7.0, only a small fraction of $\mathrm{NH}_{3}-\mathrm{N}$ should be lost into the atmosphere. This is corroborated by the fact that there is no clear decline trend of TKN content during the tests. However, attention must be paid to this issue if $\mathrm{pH}$ values of poor silages tends to go towards the alkalinity for even more prolonged storage durations.

Concerning the substrates used by microorganisms for acidification, the results suggested that substances other than WSC are the original source for organic acids production. This is based on the fact that original WSC content of fresh biomass is largely inferior to the total VFA generated during ensiling. Taking the example of fresh ensiled biomass, $28.2 \% \mathrm{VS}_{\text {added }}\left(26.0 \% \mathrm{VS}_{\text {original }}\right.$ - result not shown) of total VFA were produced after 14 days of storage, from a material with $12.0 \% \mathrm{VS}$ of original WSC. Additional information about the source of acidification products and phenomena can 
be found in the VS balance presented in Figure 3. Indeed, it can be observed that a great shift on VS structure occurred during the first 7 days of ensiling. This corresponds to the period of time where the major part of acidification took place. The major modification was the increase of water-soluble phase of VS, which varied from 13$24 \%$ VS before storage to $42-46 \% \mathrm{VS}_{\text {original }}$ after 7 days of ensiling. This was an outcome of the degradation of both non-structural and structural fractions of particulate phase. In fact, besides the reduction of Water+NDF soluble phase of particulate, there was a meaningful breakdown of (hemi-) cellulosic compounds during the first week of ensiling. Lignocellulosic degradation during early acidification may be a result of endogenous enzyme activity. Indeed, while studying grass hemicelluloses ensiling, Dewar et al. [19] reported that enzyme activity may contribute to additional sugar availability for fermentation. These additional substrate released by the particulate phase must have been a useful support to VFA production in the first week of ensiling. From 7 days of storage VS structure of biomass evolved according to the stability of silage. For low TS crops (especially for non-wilted biomass), particulate phase of VS continued to be degraded, since $\mathrm{pH}$ level turned back into bacterial and enzymatic activity range. For 92h-wilted silage, minor further increase of soluble fraction was recorded. However, we observed a slow but continuous breakdown of lignocellulose carbohydrates for this condition. Since at lower $\mathrm{pH}$ levels enzyme activity is considerably reduced, this should be a result of acid hydrolysis by VFA produced during fermentation [2,19]. After 98 days of ensiling for fresh biomass, cumulative breakdowns of $83 \%$ and $64 \%$ of hemicellulose and cellulose were detected, respectively. For $76 \mathrm{~h}-$ wilted silage, losses reached $50 \%$ for hemicellulose and $32 \%$ for cellulose. Finally, for the same ensiling duration $92 \mathrm{~h}$-wilted biomass lost $57 \%$ of 
hemicellulose and $30 \%$ of cellulose. These results show a greater extent of cell wall breakdown than previously reported results. For instance, Pakarinen et al. [20] and Menardo et al. [21] found a slight decrease of hemicellulose content during ensiling, while cellulose was not significantly degraded. In turn, other authors observed both hemicellulose and cellulose degradation with ensiling, but always below $10 \%$ of the original content [22-24]. Discrepancy between these results may be partially explained through differences in cell wall accessibility. Firstly, higher particle size was used in part of literature $[20,22,24]$. This may influence digestibility of lignocellulosic compounds during ensiling, as particle size reduction is frequently linked to the increase of the available specific surface area and to the reduction of both degree of polymerization and cellulose crystallinity [25]. Furthermore, unlike part of these works $[20,22]$, the lignification degree of the feedstock used in this study was very low, as initial lignin values ranged from 3.8-4.6\% VS. Finally, the results of the aforementioned

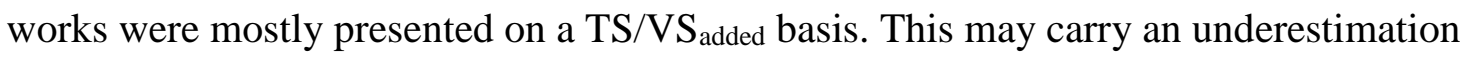
of cell wall breakdown if substantial organic matter losses occurred during ensiling.

\subsection{Evolution of BMP during storage}

Discrepancies between results of open-air and ensiling conservation were even more evident if we compare the evolution of the methane potential (BMP) along storage, Figure 4. Methane yields for the aerobic treated sample ranged between 336 and 153 $\mathrm{L} / \mathrm{kgVS}_{\text {added. }}$. While taking into account storage losses $\left(\mathrm{L} / \mathrm{kgVS}_{\text {original }}\right)$, this represented more than $80 \%$ of energy losses from 7 to 98 days of storage. On the opposite, the $96 \mathrm{~h}-$ wilted silage recorded slightly increasing values of BMP during storage, even considering organic matter losses. At the end of the 98 days, the BMP based on VS $\mathrm{V}_{\text {original }}$ of $96 \mathrm{~h}$-wilted biomass open-air stored was only $18 \%$ of the one for the ensiling of the 
same feedstock. Nevertheless, aerobic treatment does not appear to be harmful for the methane yield of 96h-wilted biomass in the first week of storage, despite important VS losses. Indeed, similar BMP values based on $\mathrm{VS}_{\text {original }}$ were obtained for open-air and ensiling of 96h-wilted biomass at 7 days. This was a result of an enhanced biochemical accessibility of aerobic storage in early days, as reflected by the higher BMP referring to $\mathrm{VS}_{\text {added }}$ for this condition after the first week. Today aerobic pretreatments for biomass are based on the delignification functions of microorganisms such as white rot fungi $[26,27]$. In this work, besides the use of a feedstock with low lignin content, no biological agent was added. Yet, fungi development that was observed during open-air storage could have the above-mentioned properties. Nevertheless, characterization of microbial biomass produced was not further investigated, since the main goal was to follow BMP evolution along storage.

Regarding ensiling, long-term storage had little effect on BMP based on VS $\mathrm{V}_{\text {original. }}$ Methane potential varied from 317 to $304 \mathrm{~L} / \mathrm{kgVS}$ original for non-wilted biomass, 307$275 \mathrm{~L} / \mathrm{kgVS}$ original for $72 \mathrm{~h}$-wilted silage and $261-280 \mathrm{~L} / \mathrm{kgVS}$ original for $96 \mathrm{~h}$-wilted biomass between 7 and 98 days of ensiling. Nevertheless, it is possible to identify distinct impacts on methane potential for different periods of storage. First of all, it is interesting to notice that, despite higher VS losses, low TS crops had higher BMP values after 7 days of ensiling. This should be a consequence of heat damage during wilting process of TS39\% silage. Indeed, as previously mentioned, extremely warm and ventilated conditions used at the end of the 96h-wilting led to important WSC losses. In addition, higher rates of hydrolysis and fermentation of lignocellulosic fractions during the first 7 days of ensiling for low TS crops should have enhanced their biochemical accessibility and therefore their methane potential. Between 7 and 14 days of storage, 
BMP increased for all silages. This corresponds to a period of organic acid production from structural carbohydrates, which rendered biomass more available for methanogens. The increase was more expressive for TS10\% and TS39\% silages, for which higher VFA accumulation occurred during this period. After 14 days and until at least the end of first month of storage, BMP based on $\mathrm{VS}_{\text {added }}$ continued to increase for all silage conditions. However at this time, stability of silage began to play an important role on methane potential conservation. Indeed, while taking into account VS losses, BMP decreased for low TS crops. This evidenced a harmful effect of secondary clostridial fermentation for energy conservation. Between 28 and 90 days of storage, instability of non-wilted and 72h-wilted silage led to losses of BMP based on $\mathrm{VS}_{\text {original }}$ of around $10 \%$.

Results of BMP based on $\mathrm{VS}_{\text {original }}$ after 98 days of storage suggest that wilting was incapable of improve energy conservation before and during ensiling. Despite its more constant and easily predictable fermentation pathways, 96h-wilted biomass probably lost part of its methane potential by heat damage (or volatilization) during wilting. Concerning low TS crops, especially fresh ensiled biomass, the gains in biochemical accessibility overcame their instability and VS losses. Moreover, the results suggest that the higher fermentation rates for low TS crops are not inevitably damaging for BMP conservation, especially for shorter storage durations.

In short, the catch crop used in these tests should be promptly ensiled after harvest if unsuitable weather conditions are present for wilting. However, one should take into attention the possibility of leachate production during ensiling of high moisture crops. Concerning these laboratorial assays, liquid effluent production was around $23 \%$ of total biomass weight (result not shown) after 98 days of ensiling for fresh biomass 
(TS10\%E). In a field scale silo, packing density should be at least equal to the one used in this work. Therefore, important leachate production should occur while using the same feedstock. Indeed, the early correlations done by Bastiman [6], Sutter [7] and Zimmer [8] predict an effluent production that range from 34 to $45 \%$ of the total weight for a silage with $10 \%$ of TS. Moreover, results presented in Figure 3 show that VS water-soluble fraction will increase along storage duration, resulting in more than $65 \%$ of total VS content after 98 days of storage for TS10\%E condition. In this case, important losses of methane potential will occur if effluent produced is not collected and promptly added to the anaerobic digester downstream.

\section{Conclusions}

Ensiling is a far more appropriated method than open-air storage for conservation of the catch crop studied before anaerobic digestion. Wilting was inefficient while witnessing unfavorable weather conditions at harvesting. Even if prolonged wilting periods under warmer/dryer conditions led to a decrease of the moisture content, it did not provide improvements on long-term conservation of the methane potential. For high moisture products, instability of fermentation is offset by gains in biochemical accessibility. In such conditions, biomass should be promptly ensiled without wilting. Liquid effluent that will likely be produced, should be collected and used for biogas production.

\section{Acknowledgements}

Rúben Teixeira Franco held a doctoral fellowship from the Rhône-Alpes region. This work has been undertaken within the SAM project (Stockage Avant Méthanisation Storage Before AD) funded by ADEME (\# 1506C0038). The authors thank the DEEP laboratory team, including David Lebouil, Hervé Perier-Camby, Nathalie Dumont and Richard Poncet for the given support during the tests. We are grateful to Franck Barra 
for his permanent availability for discussion and raw material supply. Mathilde Hardier and SUEZ are also acknowledged for the inoculum provided for the BMP tests.

\section{References}

[1] R. Teixeira Franco, P. Buffière, R. Bayard, Ensiling for biogas production: Critical parameters. A review, Biomass and Bioenergy. 94 (2016) 94-104. doi:10.1016/j.biombioe.2016.08.014.

[2] P. McDonald, A.. Henderson, S.J.. Heron, The Biochemistry of Silage, Second Edi, Chalcombe Publications, Marlow, Bucks, 1991.

[3] G. Borreani, A. Revello, S. Colombini, M. Odoardi, R. Paoletti, E. Tabacco, Fermentative profiles of field pea (Pisum sativum), faba bean (Vicia faba) and white lupin (Lupinus albus) silages as affected by wilting and inoculation, Anim. Feed Sci. Technol. 151 (2009) 316-323. doi:10.1016/j.anifeedsci.2009.01.020.

[4] S.A.Z. Mahmoud, M.M. Zaki, E.A. Saleh, Factors affecting the microbial and chemical composition of silage: IV. Effect of wilting on maize silage, Zentralblatt Fuer Bakteriol. Parasitenkunde, Infekt. Und Hyg. Zweite Naturwissenschaftliche Abteilung Mikrobiol. Der Landwirtschaft, Der Technol. Und Des Umweltschutzes. 134 (1979) 34-39. doi:10.1016/S03236056(79)80061-0.

[5] J.M. Wilkinson, A laboratory evaluation of comfrey (Symphytum officinale L.) as a forage crop for ensilage, Anim. Feed Sci. Technol. 104 (2003) 227-233.

[6] B. Bastiman, Factors affecting silage effluent production, Exp. Husb. 31 (1976) 40-46.

[7] A. Sutter, Problem of waste effluent from silage making and feeding of silage, 
Eur. Product. Agency Organ. Eur. Econ. Co-Operation. 307 (1957) 74-82.

[8] E. Zimmer, The influence of pre-wilting on nutrient losses, particularly on the formation of gas, Tagungsberichte Der Dtsch. Akad. Fur LandwirtschaftSwissenschafen Zu Berlin. 92 (1967) 37-47.

[9] J. McEniry, E. Allen, J.D. Murphy, P. O’Kiely, Grass for biogas production: The impact of silage fermentation characteristics on methane yield in two contrasting biomethane potential test systems, Renew. Energy. 63 (2014) 524-530. doi:10.1016/j.renene.2013.09.052.

[10] C.M. Carpintero, A.R. Henderson, P. Mcdonald, The effect of some pretreatments on proteolysis during the ensiling of herhage, Grass Forage Sci. 34 (1979) 311-315.

[11] L.E.R. Dawson, C.P. Ferris, R.W.J. Steen, F.J. Gordon, D.J. Kilpatrick, The effects of wilting grass before ensiling on silage intake, Grass Forage Sci. (1999) $237-247$.

http://scholar.google.com/scholar?hl=en\&btnG=Search\&q=intitle:The+effects+o f+wilting+grass+before+ensiling+on+silage+intake\#0 (accessed January 28, 2015).

[12] O. Pakarinen, A. Lehtoma, S. Rissanen, J. Rintala, Storing energy crops for methane production: Effects of solids content and biological additive, Bioresour. Technol. 99 (2008) 7074-7082. doi:10.1016/j.biortech.2008.01.007.

[13] C. Herrmann, M. Heiermann, C. Idler, A. Prochnow, Particle size reduction during harvesting of crop feedstock for biogas production I: effects on ensiling process and methane yields, Bioenergy Res. 5 (2012) 926-936. 
doi:10.1007/s12155-012-9206-2.

[14] C. Herrmann, A. Prochnow, M. Heiermann, C. Idler, Particle size reduction during harvesting of crop feedstock for biogas production II: effects on energy balance, greenhouse gas emissions and profitability, Bioenergy Res. 5 (2012) 937-948. doi:10.1007/s12155-012-9207-1.

[15] E. Kreuger, I. Nges, L. Björnsson, Ensiling of crops for biogas production: effects on methane yield and total solids determination, Biotechnol. Biofuels. 4 (2011) 44. doi:10.1186/1754-6834-4-44.

[16] M.G. Porter, R.S. Murray, The volatility of components of grass silage on oven drying and the inter-relationship between dry-matter content estimated by different analytical methods, Grass Forage Sci. 56 (2001) 405-411. doi:10.1046/j.1365-2494.2001.00292.x.

[17] P.J. Van Soest, R.H. Wine, Use of detergents in the analysis of fibrous feeds IV. Determination of plant cell-wall constituents, J. Assoc. Off. Anal. Chem. 50 (1967) 50-55.

[18] C. Holliger, M. Alves, D. Andrade, I. Angelidaki, S. Astals, U. Baier, et al., Towards a standardization of biomethane potential tests, Water Sci. Technol. (2016) 1-9. doi:10.2166/wst.2016.336.

[19] W.A. Dewar, P. McDonald, R. Whittenbury, The hydrolysis of grass hemicelluloses during ensilage, J. Sci. Food Agric. 14 (1963) 411-417. doi:10.1002/jsfa.2740140610.

[20] A. Pakarinen, P. Maijala, S. Jaakkola, F.L. Stoddard, M. Kymäläinen, L. Viikari, 
Evaluation of preservation methods for improving biogas production and enzymatic conversion yields of annual crops, Biotechnol. Biofuels. 4 (2011) 20. doi:10.1186/1754-6834-4-20.

[21] S. Menardo, P. Balsari, E. Tabacco, G. Borreani, Effect of Conservation Time and the Addition of Lactic Acid Bacteria on the Biogas and Methane Production of Corn Stalk Silage, Bioenergy Res. 8 (2015) 1810-1823. doi:10.1007/s12155015-9637-7.

[22] Y. Chen, R. Sharma-Shivappa, C. Chen, Ensiling agricultural residues for bioethanol production, Appl. Biochem. Biotechnol. (2007) 80-92. doi:10.1007/s12010-007-0030-7.

[23] Y. Zheng, C. Yu, Y. Cheng, R. Zhang, B. Jenkins, J.S. Vandergheynst, Effects of ensilage on storage and enzymatic degradability of sugar beet pulp, Bioresour. Technol. 102 (2011) 1489-1495. doi:10.1016/j.biortech.2010.09.105.

[24] S.T. Desta, X. Yuan, L. Junfeng, T. Shao, Ensiling Characteristics, structural and nonstructural carbohydrate composition and Enzymatic Digestibility of Napier grass Ensiled with Additives, Bioresour. Technol. (2016). doi:10.1016/j.biortech.2016.09.068.

[25] V.B. Agbor, N. Cicek, R. Sparling, A. Berlin, D.B. Levin, Biomass pretreatment: fundamentals toward application, Biotechnol. Adv. 29 (2011) 675-685. doi:10.1016/j.biotechadv.2011.05.005.

[26] P. Kumar, D.M. Barrett, M.J. Delwiche, P. Stroeve, Methods for pretreatment of lignocellulosic biomass for efficient hydrolysis and biofuel production, Ind Eng Chem Res. 48 (2009) 3713 - 3729. doi:10.1021/ie801542g. 
[27] F. Monlau, A. Barakat, E. Trably, C. Dumas, J.-P. Steyer, H. Carrère, Lignocellulosic Materials Into Biohydrogen and Biomethane: Impact of Structural Features and Pretreatment, Crit. Rev. Environ. Sci. Technol. 43 (2013) 260-322. doi:10.1080/10643389.2011.604258. 
Table 1 - Chemical characteristics of feedstock and impact of wilting

\begin{tabular}{cccc}
\hline Biomass & Non-wilted & 72h-wilted & 96h-wilted \\
\hline Condition $^{\text {a }}$ & TS10\%E & TS14\%E & TS39\%E / TS39\%A \\
\hline pH $^{\text {TS }^{\mathrm{b}}}$ & 6.4 & 6.2 & 5.8 \\
\hline VS $^{\mathrm{b}}$ & 10.1 & 14.1 & 38.7 \\
\hline VFA $^{\mathrm{c}}$ & 8.4 & 11.6 & 32.3 \\
\hline WSC $^{\mathrm{c}}$ & 0.3 & 0.4 & 0.1 \\
\hline HEM $^{\mathrm{c}}$ & 12.0 & 12.7 & 5.7 \\
\hline CEL $^{\mathrm{c}}$ & 11.3 & 10.1 & 10.5 \\
\hline LIG $^{\mathrm{c}}$ & 20.4 & 18.3 & 16.8 \\
\hline TKN $^{\mathrm{c}}$ & 3.8 & 3.4 & 3.0 \\
\hline $\mathbf{N H}^{\mathrm{s}-\mathbf{N}^{\mathrm{d}}}$ & 4.7 & 5.1 & 5.1 \\
\hline & 2.6 & 7.0 & 4.5 \\
\hline
\end{tabular}

${ }^{\mathrm{a}} \mathrm{TS} 10 \% \mathrm{E}$ represents the ensiling of non-wilted biomass; TS14\% $\mathrm{E}$ concerns the ensiling of the $72 \mathrm{~h}-$ wilted biomass; TS39\%E and TS39\%A symbolize the ensiling and open-air storage of the 96-wilted biomass, respectively.

Results presented as ${ }^{\mathrm{b}} \%$ of total sample weight; ${ }^{\mathrm{c}} \% \mathrm{VS}_{\text {original }},{ }^{\mathrm{d}} \% \mathrm{TKN}$ 
Table 2- Fermentation profiles of biomass over storage time $\left(\% \mathrm{VS}_{\text {added/original }}\right.$ unless otherwise specified)

\begin{tabular}{|c|c|c|c|c|c|c|c|c|c|c|}
\hline \multirow[b]{2}{*}{ Condition } & \multirow{2}{*}{$\begin{array}{c}\text { Storage } \\
\text { duration } \\
\text { (days) }\end{array}$} & \multirow{2}{*}{$\begin{array}{c}\text { VS } \\
\text { losses }\end{array}$} & \multicolumn{8}{|c|}{ Chemical characteristics ${ }^{\text {a }}$} \\
\hline & & & $\mathrm{pH}$ & $\mathrm{LA}^{\mathrm{b}}$ & $\mathrm{AA}^{\mathrm{b}}$ & $\mathrm{BA}^{\mathrm{b}}$ & VFA $^{b}$ & $\mathrm{WSC}^{\mathrm{b}}$ & $\begin{array}{c}\mathrm{NH}_{3}-\mathrm{N} \\
(\% \mathrm{TKN})\end{array}$ & $\mathrm{TKN}^{\mathrm{c}}$ \\
\hline \multirow{5}{*}{ TS10\%E } & 0 & - & 6.4 & 0.0 & 0.0 & 0.2 & 0.3 & 12.0 & 2.6 & 4.7 \\
\hline & 7 & 5.3 & 4.0 & 18.9 & 2.1 & 0.0 & 22.1 & 2.3 & 8.2 & 4.7 \\
\hline & 14 & 8.1 & 4.2 & 23.1 & 3.3 & 0.0 & 28.2 & 0.3 & 12.3 & 4.7 \\
\hline & 28 & 20.9 & 6.7 & 0.5 & 5.0 & 6.2 & 17.6 & 0.4 & 23.7 & 5.0 \\
\hline & 98 & 25.8 & 5.6 & 0.0 & 7.2 & 8.3 & 19.5 & 0.1 & 40.2 & 5.6 \\
\hline \multirow{5}{*}{ TS14\%E } & 0 & - & 6.2 & 0.0 & 0.0 & 0.3 & 0.4 & 12.7 & 7.0 & 5.1 \\
\hline & 7 & 3.9 & 4.2 & 18.9 & 2.5 & 0.0 & 22.4 & 0.3 & 12.7 & 5.3 \\
\hline & 14 & 5.2 & 4.4 & 17.9 & 3.6 & 0.0 & 22.6 & 0.4 & 15.3 & 5.3 \\
\hline & 28 & 10.4 & 5.9 & 8.1 & 7.9 & 0.9 & 18.6 & 0.8 & 24.0 & 6.0 \\
\hline & 98 & 16.8 & 7.0 & 0.0 & 6.4 & 5.5 & 13.6 & 0.2 & 37.0 & 6.2 \\
\hline \multirow{5}{*}{ TS39\%E } & 0 & - & 5.8 & 0.0 & 0.0 & 0.1 & 0.1 & 5.7 & 4.5 & 5.1 \\
\hline & 7 & 2.1 & 4.9 & 7.7 & 1.2 & 0.0 & 9.4 & 2.9 & 11.4 & 5.7 \\
\hline & 14 & 2.6 & 4.6 & 10.8 & 1.3 & 0.0 & 12.5 & 1.6 & 13.1 & 5.4 \\
\hline & 28 & 3.0 & 4.4 & 11.0 & 1.8 & 0.2 & 13.6 & 0.6 & 12.9 & 5.5 \\
\hline & 98 & 3.4 & 4.4 & 11.6 & 2.6 & 1.0 & 16.2 & 0.6 & 12.9 & 5.5 \\
\hline \multirow{5}{*}{ TS39\% A } & 0 & - & 5.8 & 0.0 & 0.0 & 0.1 & 0.1 & 5.7 & 4.5 & 5.1 \\
\hline & 7 & 21.9 & 8.4 & 1.5 & 1.5 & 0.0 & 3.3 & 0.1 & 34.7 & 4.7 \\
\hline & 14 & 38.6 & 9.0 & 0.6 & 0.4 & 0.0 & 1.1 & 0.2 & 40.9 & 3.8 \\
\hline & 28 & 48.3 & 9.3 & 0.4 & 0.0 & 0.2 & 0.7 & 0.2 & 46.8 & 3.8 \\
\hline & 98 & 67.8 & 9.6 & 0.0 & 0.0 & 0.0 & 0.0 & 0.0 & 14.1 & 2.0 \\
\hline
\end{tabular}

${ }^{\mathrm{a}}$ LA stands for Lactic Acid, AA for Acetic Acid and BA for Butyric Acid; ${ }^{\mathrm{b}}$ results based on $\% \mathrm{VS}_{\text {added}}$;

${ }^{\mathrm{c}}$ results based on $\% \mathrm{VS}_{\text {original }}$ 


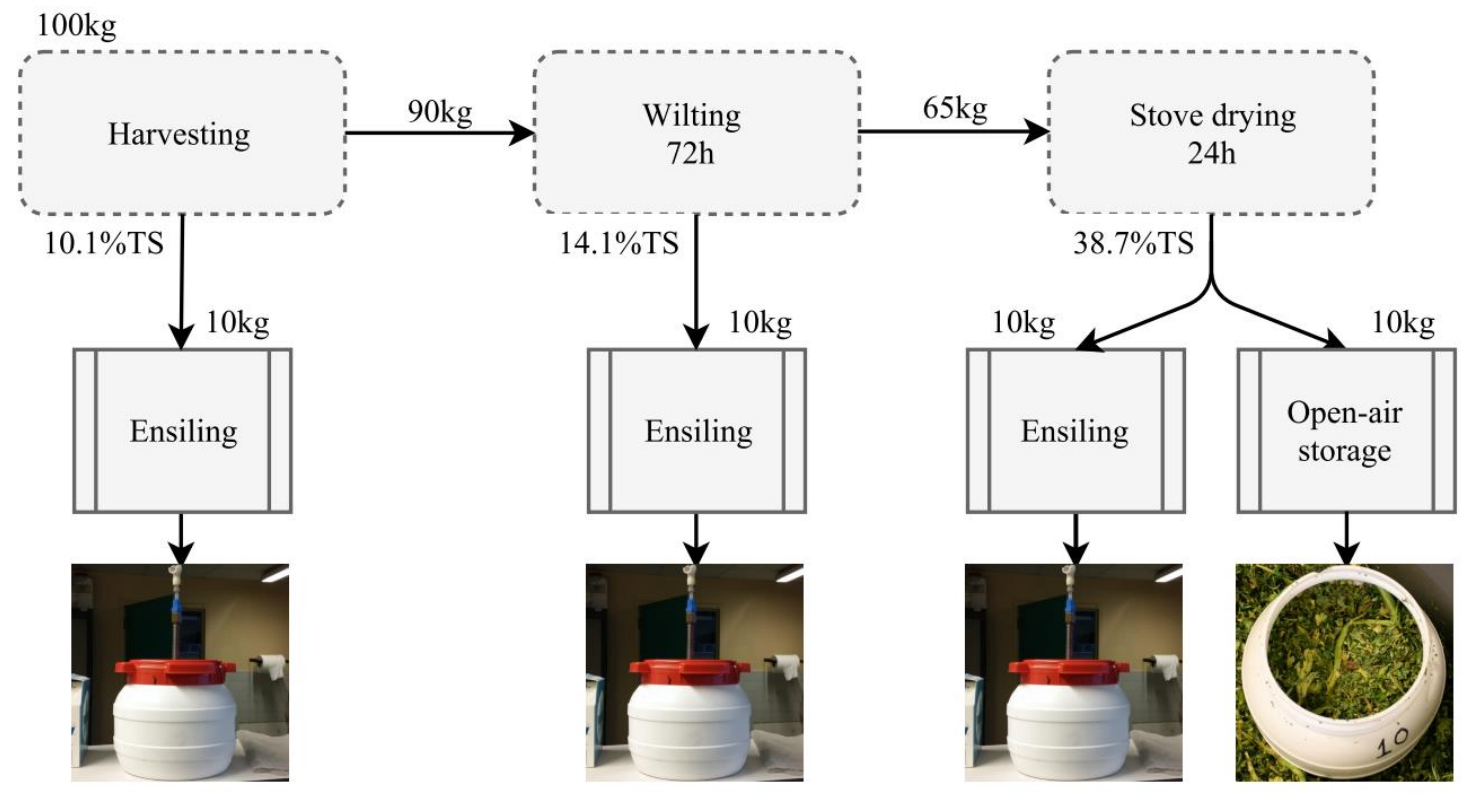

Figure 1 - Storage preparation procedure 


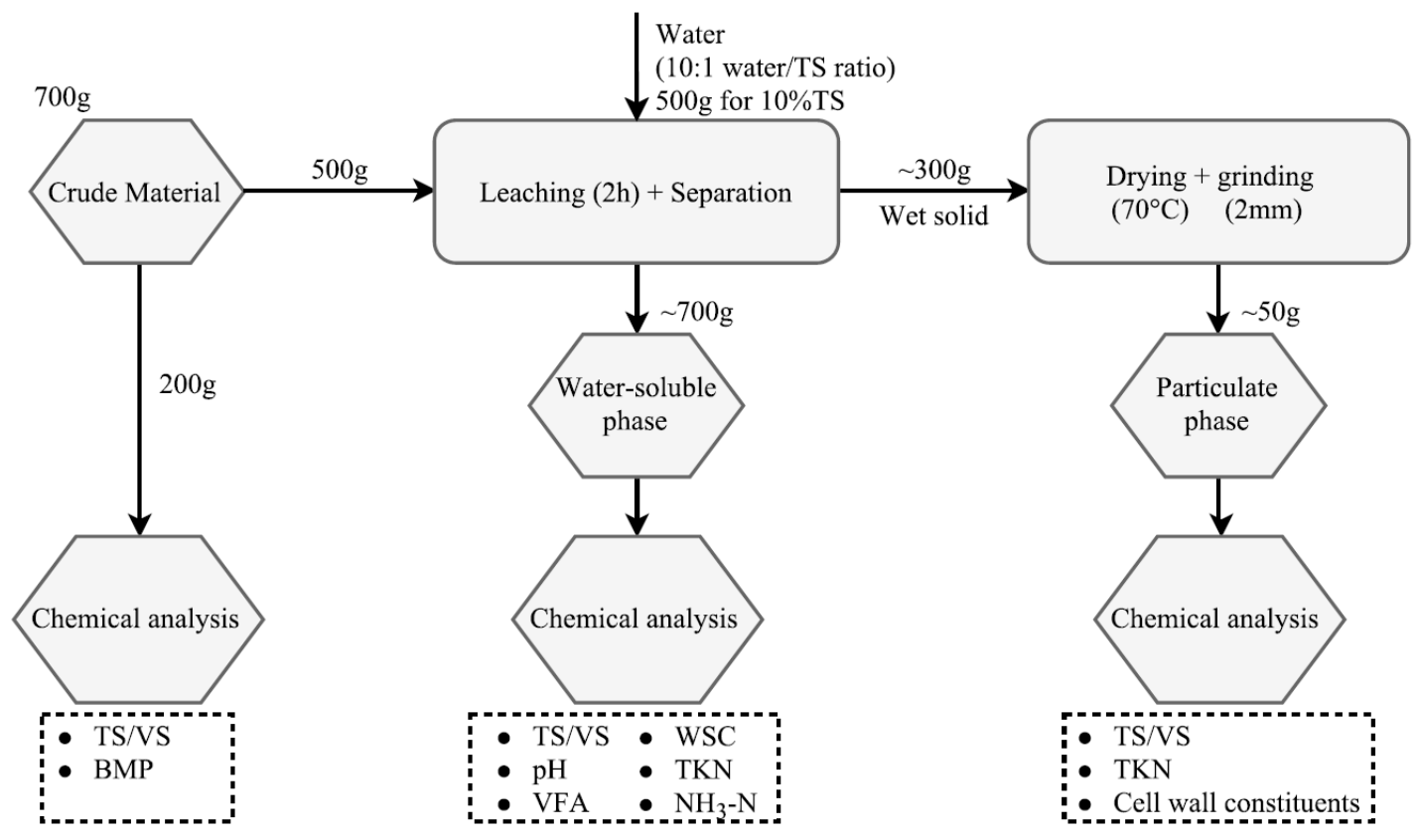

Figure 2 - Chemical analysis procedure after sampling 
(A)

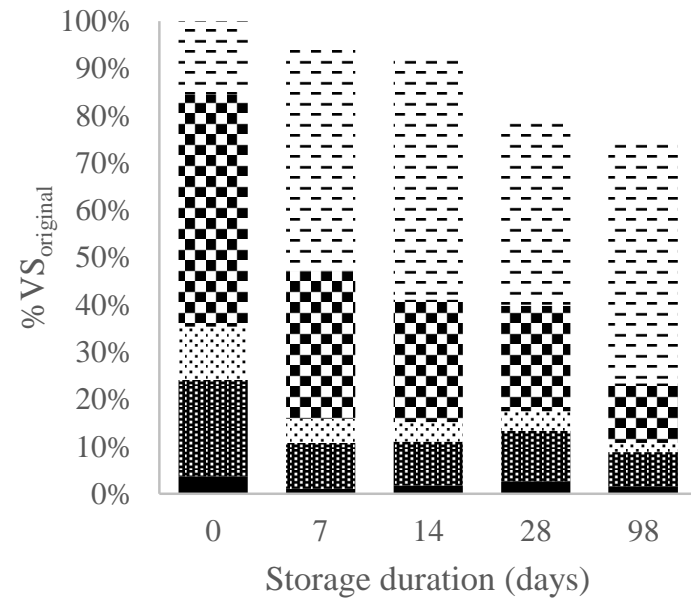

-- Soluble Le Particulate: W+NDF

Particulate: HEM

䀧 Particulate: CEL

- Particulate: LIN

(C)

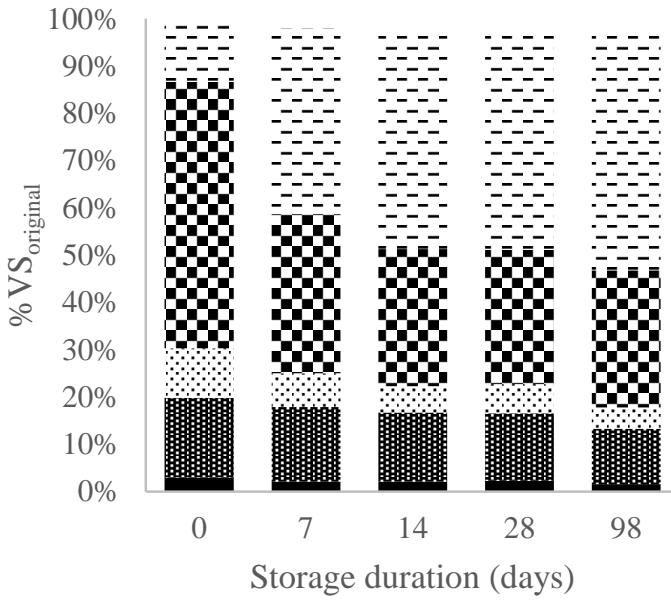

$\because$ Soluble

Particulate: HEM

- Particulate: LIN
(B)

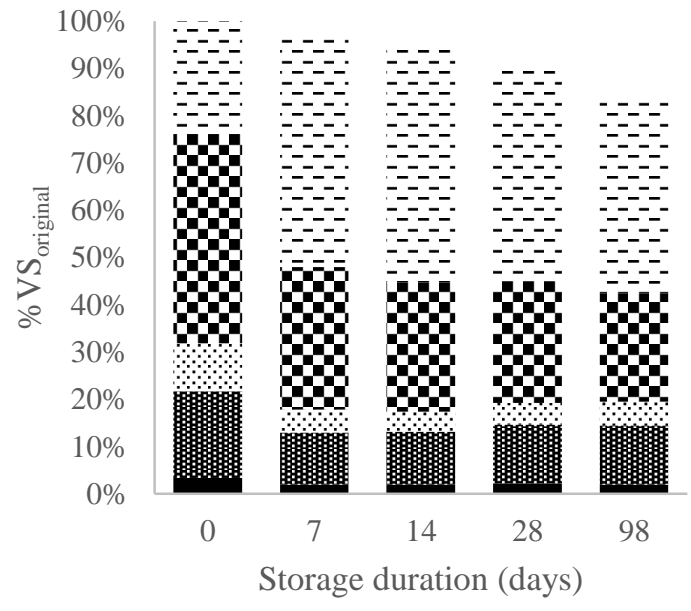

-- Soluble $\quad$ Particulate: $\mathrm{W}+\mathrm{NDF}$

$\therefore$ Particulate: HEM Particulate: CEL

- Particulate: LIN

(D)

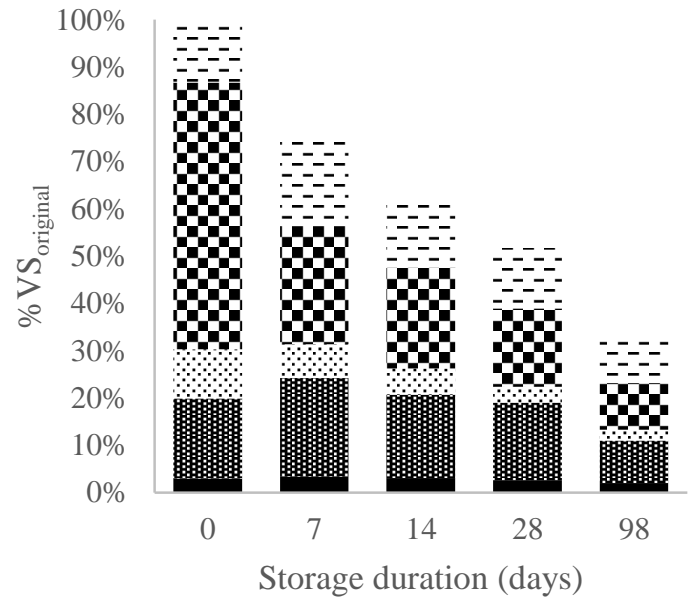

-Soluble - Particulate: W+NDF

$\therefore$ Particulate: HEM Particulate: CEL

- Particulate: LIN

Figure 3 - Total volatile solids balance for: (A) TS10\%E; (B) TS14\%E; (C) TS39\%E; (D) $\mathrm{TS} 39 \% \mathrm{~A}$ 
(A)

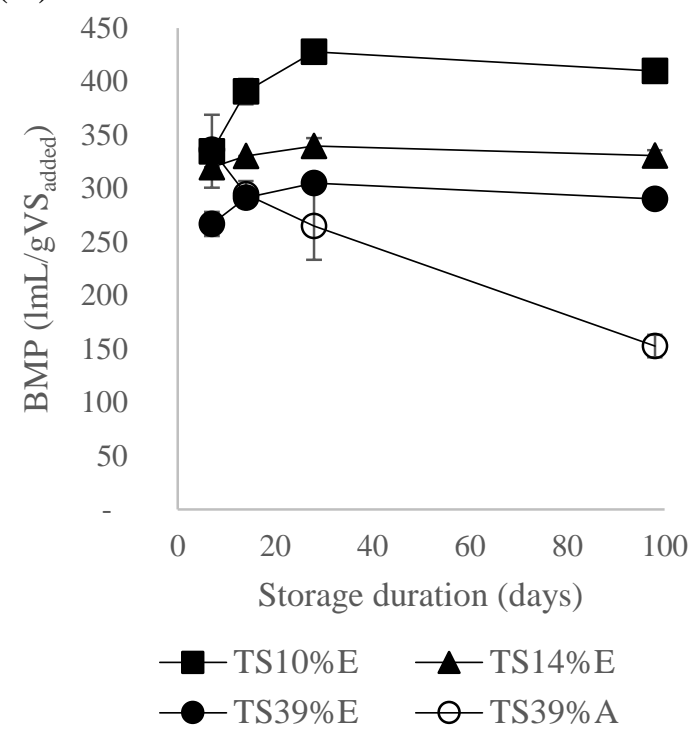

(B)

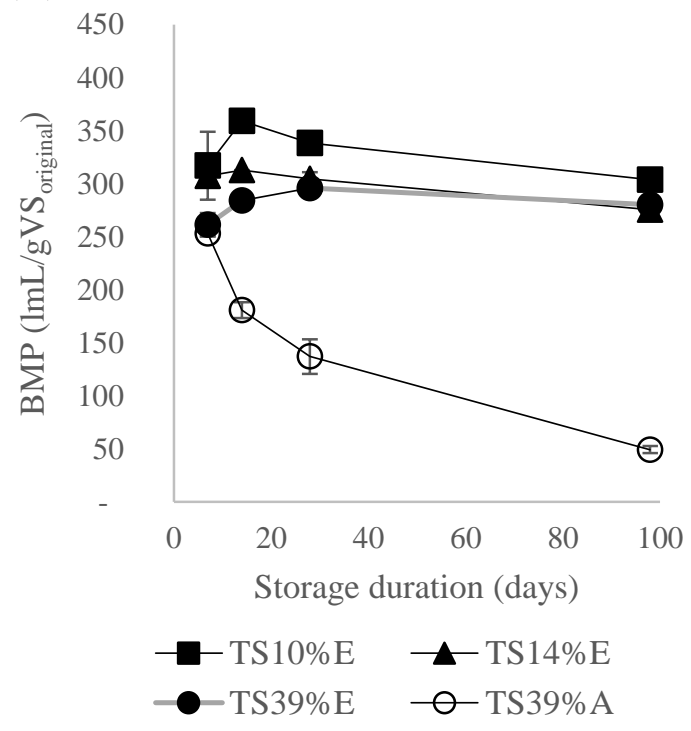

Figure 4 - BMP evolution over storage duration. (A): methane potential based on $\mathrm{VS}_{\text {added }}$ (B): methane potential based on $\mathrm{VS}_{\text {original, }}$, therefore considering storage losses. 